\title{
Analysis of The Decision to Buy or Lease Business Space at PT UMB
}

\author{
Sri Lusiana ${ }^{1}$, Budi Frensidy ${ }^{2}$ \\ \{srilusiana@hotmail.com¹․, frensidy@gmail.com²
}

Faculty of Economics and Business, University of Indonesia, Indonesia ${ }^{1}$; Graduate School of Business, Atma Jaya Catholic University of Indonesia, Indonesia ${ }^{2}$

\begin{abstract}
The franchise business of minimarket requires business stores to place merchandise. It can be obtained in several ways. Three of them are buying, renting, and buying with loan. The purpose of this study is to apply the NPV (Net Present Value) and APV (Adjusted Present Value) analysis to choose the business store. NPV and APV analysis are used to obtain the most favorable choice for business store of a minimarket. The results of the analysis carried out on the data and assumptions obtained, it can be concluded that there is no choice between renting and buying with loan that is always superior to all conditions in providing business space. Many factors influence every decision, including the percentage of rental prices compared to the value of land and buildings, the growth of land price, and the amount of discount rates or the returns expected by the company.
\end{abstract}

Keywords: NPV analysis, APV analysis, discount rate

\section{Introduction}

Minimarket franchise business gives two options in store ownership, which are buying or renting. Buying becomes a better option than renting when the company has enough capital. Buying becomes the better option due to the assumption that the lands price in Jakarta and around keep increasing from time to time.

From a pure financial point of view, the decision of buying or renting depends on how long the asset will be kept and how much the cost spent to obtain said asset.

Option to rent comes into consideration when the company opts to shift the risk of failure in business. Renting option put into consideration is operating lease. But the operating lease option has risk in price increase after renting period is over for rent extension. In certain place, the increase could go up to $10 \%$ higher from the previous year's price.

Franchise in minimarket business has existed since 2006. Usually, the company buys the store for the minimarket assuming that the company has a chance to get profit from the increase in fixed asset's price when they sell it.

In doing this discussion and research, the decision in buying or renting will be based on assumption that the asset in consideration is land and building and by considering the profit and loss of the company in the year of research.

This research applied NPV and cash flow estimation to give the company an assessment of the future investment in expanding the minimarket network owned by PT UMB. The calculation is done by considering components such as interest and discount rate, capital gain, 
tax shield, and other components like minimarket franchise contract duration, which last 5 years. Gross profit margin is determined together and franchise fee is done once at the beginning, while royalty is calculated from net sales/turnover.

This research is done with purposes according to the problems stated previously. This research is done by studying, obtaining, and analyzing data from various sources to gain information for the result and drawing useful conclusion.

The purposes of this research are (1) to find the most profitable option between buying and operating lease in increasing the number of store for minimarket franchise; (2) to find the most profitable option between financial lease and operating lease if the company has no cash fund; (3) to find out if the company needs to consider the capital gain from a property when choosing the investment.

\section{Literature review}

\subsection{Lease}

Leasing is an agreement in which a lessor gives right to a lessee to use an asset for a certain period agreed upon by both sides. (PSAK 30).

Based on PSAK 73, lease is a contract, or part of a contract, which gives right of underlying assets for a period of time in change of a payment. Lease for a business is differentiated into two, which are Operating Lease and Finance Lease.

Time stipulation to capitalize the lease is the same as the common treatment in buying asset. For example, the first and second stipulation mentioned previously could be interpreted as the asset will be bought at the end of the leasing period. While the last two stipulations capitalize the long-term lease [1].

\subsection{Franchise}

Isaac Singer, founder of Singer Sewing Company, first adopted franchise business around 1851. Known as "the father of modern-day franchising", Singer is one of the first to develop franchise contract to distribute the sewing machines widely to various areas. Singer contracted salesman, gave rights to sell their machines with license fee in certain areas that is specifically determined [2].

As time goes, franchise business offered the franchisor and franchisee a mechanism for a chance of success. Franchising concept has proven success even in the thought market, and possibly has shown that this concept is considerably safe to run a business with.

Option for fulfilling the company resources or activity in the form of make or buy (selfmade or outsourcing/sub contract) and the option in expanding the business through adding the number of company-owned store or through franchise is often connected to the Governance Structure. And so are the decision-making system, operational control, and the company incentive system.

Governance structure describes the process and system that control the operational activities of an organization or a community. In other words, governance structure describes the distribution system of the rights and responsibilities related to the operational activities in the organization. Level of complexity in making a decision and monitoring, in accordance with unpredictable factors faced by the company, will influence the form of governance structure chosen. 
Whatever choice of governance structure will be used, the partner will be responsible for the brand they are using. Since the store will carries the brand from the main company, the partner moves in the business model called franchising.

Based on the governance structure, the franchise model can be said to have special characteristic, which is allowing the dual-structure in its concept of business expansion. Hierarchy oriented expansion is more known as company-owned or in some business in Indonesia it is called as regular booth. While the market oriented is known more as franchise.

\section{Buy or lease}

One of the common questions asked by the business owner in running the business is whether buying or renting business room is better option. The most important thing they want to know is the amount of money they have to pay.

The decision to either buy or rent the space needed for business activities is the most important decision to make. Even though the cost for space is a significant business cost, the decision to buy or rent is more than just a financial decision. This decision is focused on the analytical frameworks such as:

\subsection{The effect of taxation on buying or renting decisions}

Tax shield is very important to assess the economical worth of each business. In running a business, a company must be able to manage the tax in order to save the tax cost. In the case of buying or renting a building or property, tax saving calculation have to be done. In buying, one of the advantages in taxation can be obtain by imposing depreciation to reduce the amount of annual tax. But if the company has decided to rent (operating lease), renting cost can be imposed to reduce the annual tax.

\subsection{Cash flow estimation}

Cash flow estimation is done by calculating the net present value (NPV) that the company will receive and spend on the assets which are bought or leased on a discount rate that reflect the risk and uncertainty the company will face in the future.

\subsection{NPV analysis}

"NPV is the financial management goal of all companies to increase or create added value for their shareholders. The NPV criteria also speak of the added value of a project or investment for a company, especially shareholders. NPV is the difference between the amount of cash generated by an investment project (after calculating the time value of money) and the value of the investment required or the difference in present value (PV) of a project and initial investment." [3]

In calculating the NPV for an analysis of buying or renting, the best way to make a fair comparison between the costs of acquiring assets through purchases and the costs of acquiring assets through leasing is to take the following three-step approach:

a. Discount all cash flow at an interest rate after tax. 
b. Calculate the NPV of the asset purchase cost. The cast flows included here are initial asset costs, any tax savings that will arise as a result of asset purchases, and any expected residual value.

c. Calculate the NPV of the asset rental fee. The cash flows included here are periodic rental fees and tax relief on rental costs.

d. Compare the two alternatives, then choose the one that is more profitable for the company. The lowest cost NPV option is the preferred method for acquiring assets.

\subsection{Appraisal and budgeting for companies with loans}

In general, for a company with a loan, investment valuation can be done with three approaches, namely Adjusted Present Value (APV), Flow to Equity (FTE), and Weighted Average Cost of Capital (WACC).

This literature used APV approach, which is carried out by assuming that the value of a company's project with debt is the value of the company's project without debt (NPV) plus the side effects of debt (NPVF). Side effects of the intended debt consist of:
a. Tax subsidies on debt,
b. Costs of issuing new shares,
c. Costs incurring when the company is experiencing financial difficulties, and
d. Subsidies for debt financing.

\section{Methodology and data analysis}

\subsection{Methodology}

This study uses a comparative research method with quantitative techniques. Comparative research illustrates the comparison between two or more variables. This study is done by comparing and analyzing the sensitivity of NPV and estimated cash flow from 3 decision choices

Sensitivity analysis is performed to assess the effects that occur due to changes in assumptions in the calculation of cash flows. This analysis is also used to assess the level of sensitivity of changes in cash flow if the factors that influence the amount of cash flow are changed.

The equation used to calculate NPV is:

$$
\begin{aligned}
& \mathrm{NPV}=\mathrm{PV} \text { all cash flows from the project / investment }- \text { initial investment } \\
& \mathrm{NPV}=\mathrm{PV}-\mathrm{I}_{0} \\
& \mathrm{NPV}=\sum_{i=1}^{n} \frac{C F_{i}}{(1+k)^{i}}-I_{0} \quad \text { or } \\
& \mathrm{NPV}=\frac{C F_{1}}{1+k}+\frac{C F_{2}}{(1+k)^{2}}+\cdots+\frac{C F_{n}}{(1+k)^{n}}-I_{0}
\end{aligned}
$$

Ref:

$I_{0} \quad=$ initial investment

$C F_{i}=$ cash flow of year- $i$

$k=$ discount rate or expected return on investment. 
If the NPV is positive, it means that the investment increases the value of the company. Conversely, NPVs from negative investment will reduce the value of the company if done. The criteria for investment acceptance or rejection are:

If NPV $>0$, then the investment plan is accepted

If NPV $<0$, then the investment plan is denied

Net present value (NPV) of projects that use loans as funding is determined by first seeking tax savings from loan interest (NPV debit tax shield) which is the NPV of side effects (NPVF).

$$
\begin{aligned}
& A P V=N P V+N P V_{\text {debt tax shield }} \\
& N P V_{\text {debt tax shield }}=\sum_{t=1}^{n} \frac{\text { tax from interest loan }}{(1+\text { interest rate })^{t}}
\end{aligned}
$$

\subsection{Data Analysis}

This study uses secondary data obtained by reading and analyzing information provided from 4 shops offered for buying or renting by PT UMB. The sample data of this study was taken in 2018, which consisted of land prices, building prices, depreciation, rental prices, loan interest.

The discount rate is set at the return of a banking product called bancassurance, a type of deposit issued by insurance companies and marketed by banks.

Table 1. Object of Research

\begin{tabular}{|l|r|r|r|r|}
\hline \multicolumn{1}{|c|}{ Description } & \multicolumn{1}{c|}{ Store 1 } & \multicolumn{1}{c|}{ Store 2 } & \multicolumn{1}{c|}{ Store 3 } & \multicolumn{1}{c|}{ Store 4 } \\
\hline Land Price & 714.226 .462 & 2.077 .399 .151 & 2.390 .340 .285 & 1.990 .324 .461 \\
\hline Building Price & 1.285 .773 .538 & 3.922 .600 .849 & 1.609 .659 .715 & 1.009 .675 .539 \\
\hline Total Land \& Building Price & 2.000 .000 .000 & 6.000 .000 .000 & 4.000 .000 .000 & 3.000 .000 .000 \\
\hline Depreciation & 64.288 .677 & 196.130 .042 & 80.482 .986 & 50.483 .777 \\
\hline Rent Price & 100.000 .000 & 300.000 .000 & 300.000 .000 & 200.000 .000 \\
\hline Increase of Rent Price @ 5 years & $10,2 \%$ & $10,2 \%$ & $10,2 \%$ & $10,2 \%$ \\
\hline $\begin{array}{l}\text { Comparison of Rent Price to Total } \\
\text { Land \& Building Price (Year 0) }\end{array}$ & $5,00 \%$ & $5,00 \%$ & $7,50 \%$ & $6,67 \%$ \\
\hline
\end{tabular}

\section{Research result and discussion}

The APV calculation results for the 4 shops offered if purchased by taking out a loan are as follows:

Table 2. APV Calculation Result

\begin{tabular}{|c|r|r|r|r|}
\hline Description & \multicolumn{1}{|c|}{ Store 1 } & \multicolumn{1}{|c|}{ Store 2 } & \multicolumn{1}{|c|}{ Store 3 } & \multicolumn{1}{c|}{ Store 4 } \\
\hline NPV & -1.057 .110 .051 & -3.179 .442 .085 & -2.253 .997 .522 & -1.711 .523 .371 \\
\hline NPVF & 145.300 .654 & 435.901 .963 & 290.601 .309 & 217.950 .981 \\
\hline APV & -911.809 .397 & -2.743 .540 .122 & -1.963 .396 .213 & -1.493 .572 .389 \\
\hline
\end{tabular}


Overall, from this analysis, it can be said that there is no choice that is always superior to all conditions in providing business space for Store 1, Store 2, Store 3, and Store 4.

These different conditions are influenced by:

a. Percentage of rental price compared to land and building values.

The 5\% percentage of building rental prices from Stores 1 and 2 resulting in a different analysis from the analysis of Store 3 which has a percentage of $7.5 \%$ and Store 4 which has a percentage of $6.67 \%$. Based on the percentage of the rental price it can be said that the business space for Store 1 and Store 2 is more expensive than the business space for Store 3 and Store 4. When the rental price percentage is higher than 5\%, the option to rent is not the main choice in providing business space. Conversely, when the percentage of the rental price to the price of land and buildings is 5\%, the option of renting has advantages compared to other options. This choice is also influenced by other factors such as discount rate, time period, etc.

\section{b. Loan Interest Rates.}

The amount of loan interest received by PT UMB affects the choices made in the provision of business space. The amount of interest provides the value of tax savings since loan interest can be charged to the financial statements.

\section{c. Growth from Commercial / Capital Gain Prices}

The increase in land prices by $5.85 \%$ per year was obtained from the average quarterly growth of the retail sales index in the Jabodetabek area. This quarterly growth value was obtained from the official website of Bank Indonesia. The yearly land price growth generates added value to the selling price of assets. This value gives PT UMB an advantage if it buys building assets, compared to renting a building in providing business space in its business. Capital gains play an important role in deciding to buy an asset.

\section{d. Discount Rate.}

The discount rate is the main factor influencing decision-making. Adding and decreasing $2 \%$ each during discount rate analysis is resulting in a different result in the calculation, which could lead to different decisions.

For example, when the choice in Store 1 has a discount rate of $10 \%$ the option to rent is superior to the other 2 choices. The resulting yield becomes different when the discount rate is reduced by $2 \%$, which is $8 \%$. The resulting choice is to buy with a loan.

Sensitivity analysis of the study period did not significantly affect the results of the study. Choices made over a 15 -year period will produce the same analysis over a 20 -year period.

\section{Conclusion}

Overall from this analysis it can be said that there is no choice that is always superior to all conditions in providing business space for Store 1, Store 2, Store 3, and Store 4. These different conditions are influenced by:

a. Percentage of rental price compared to land and building values.

b. Growth from land prices or capital gains.

c. Decrease in building value.

d. The amount of discount rate or return value expected by the company. 
Sensitivity analysis of the study period did not affect the results of the study. Choices made over a 15 -year period will produce the same analysis over a 20 -year period.

Companies need to consider capital gains from property in investment selection. Without capital gains, investment in land and buildings is not attractive. The amount of capital gain value needed to make a decision to buy must be above $6.07 \%$ for Store $1 ; 6.15 \%$ for Store 2; $2.60 \%$ for Store 3; and $4.33 \%$ for Store 3.

Based on the results of the study, the option of buying with cash belonging to the company is always the last choice because other options provide less tax savings. Similarly, in terms of costs, the choice of buying land and buildings has a greater cost than the choice of renting.

\section{Implications / limitations and suggestions for further research}

An important implication of the study is knowing that the company needs to consider carefully in determining whether the assets to be used in operations are better obtained by buying directly with funds from bank loans or by renting by taking into account several factors as follows:

- The amount of interest on bank loan,

- The most efficient bank loan payment projections,

- The amount of rent payments and features offered by the owners listed in the lease agreement.

- Capital gains and residual values to be obtained at the end of the rental period, if the company decides to buy the asset directly.

The limitation of the study is due to the fact that the analysis and calculations carried out in this study are using several assumptions, and it is very possible to get different results from the results of the author if the assumptions used are different.

\section{Reference}

[1] S. Ross, R. Westerfield, J. Lim, R. Tan, and H. Wong: Corporate Finance Asia Global Edition: McGraw-Hill Education (2015)

[2] F. Slamet: Pengantar Manajemen Waralaba, PT Indeks, Jakarta (2016)

[3] B. Frensidy: Matematika Keuangan, 3rd ed. Salemba Empat, Jakarta (2010)

[4] Association International Franchise: What is a Franchise. Accessed from https://www.franchise.org/what-is-a-franchise (2018)

[5] M. Corporation: McDonalds 2017 Annual Report. Accessed from https://corporate.mcdonalds.com/content/dam/gwscorp/investor-relations-content/annualreports/McDonald\%27s 2017 Annual Report.pdf (2018)

[6] S. Corporation: Starbucks Fiscal 2017 Annual Report.. Accessed from https://s22.q4cdn.com/869488222/files/doc_financials/annual/2017/01/FY17-Starbucks-

Form-10-K.pdf (2018)

[7] B. Rachmadi: Model pengembangan kinerja franchise di Indonesia : peranan governance structure, orientasi kewirausahaan (entrepreneurial orientation) dan sumber daya berbasis pengetahuan (knowledge-Based resources). Thesis, University of Indonesia (2007) 
